\title{
PENGARUH JUMLAH PENDUDUK TERHADAP PERTUMBUHAN EKONOMI DI KOTA LHOKSEUMAWE
}

\author{
Nanda Fitri Yenny ${ }^{* a}$ Khairil Anwar ${ }^{* b}$ \\ *Fakultas Ekonomi dan Bisnis Universitas Malikussaleh \\ a Corresponding author: nandafitriyenny@gmail.com \\ b khairil.anwar.semsi@gmail.com
}

A R T I C L E I N F O R M A T I O N

Keywords:

Total Population and Economic Growth

\section{A B S T R A C T}

This research was conducted in Lhokseumawe City and the aim is to see the effect of population on economic growth in the city of Lhokseumawe. The data used in this research is secondary data sourced from the Central Statistics Agency (BPS) for 18 years from 2001-2018. The data analysis method used in this research is simple linear regression. The results of this study indicate that the population variable does not have a negative effect on population growth and the magnitude of the influence of the population variable on economic growth is $0.0938(9.38 \%)$.

\section{PENDAHULUAN}

Salah satu indikator keberhasilan pembangunan ekonomi adalah pertumbuhan ekonomi. Namun, tidak semua negara mampu mencapai pertumbuhan ekonomi yang baik. Pertumbuhan ekonomi untuk besarnya penerimaan daerah tersebut dikarenakan penerimaan masyarakatnya meningkat.

Dari jumlah penduduk merupakan kesetaraan dinamika dari menambah dan menguruangi jumlah penduduk, pertamabah pendduuk disekarenakan angka kelhiran dan pengurangan penduduk karena adanya kematian penduduk atau migrasi. (Rochaida, 2016).

Berdasarkan data jumlah penduduk Indonesia tahun 2019, dengan melihat laju pertumbuhan setiap tahunnya. Jika kita mengacu pada data yang dikeluarkan bank dunia, yaitu laju pertumbuhan penduduk Indonesia sebesar 1,2\% tahun maka jumlah penduduk tahun 2019 mencapai 265 juta jiwa.

Kota Lhokseumawe bukan salahsatu provinsii yang memiliki pertumbuhan penduduk yang tinggi. Namun, pertumbuhan penduduk akan berpengaruh terhadap pertumbuhan ekonomi. Selama dalam jangka waktu 5 tahun dimulai 20012005 diperoleh bahwa di tahun 2001 jumlahpenduduk di Kota Lhokseumawe yaitu sebesar 163.231 dengan pertumbuhan ekonomi sebesar $-0,44 \%$, lalu ditahun 2002 jumlah penduduk meningkat dari tahun sebelumnya menjadi 165.281 jiwa dengan tingkat pertumbuhan ekonomi sebesar 7,96\%, lalu ditahun 2003 jumlah penduduk sebesar 167.362 jiwa dengan angka pertumbuhan ekonomi sebesar 3,70\%, dan ditahun 2004 angka jumlah penduduk sebesar 138.663 dengan tingkat pertumbuhan ekonomi sebesar $1,76 \%$ dan terkahir angka jumlahpenduduk ditahun 2005 sebesar 154.743 meningkat dar tahunsebelumnya dengan tingkat pertumbuhan ekonomi sebesar $1,22 \%$.

Untuk melihat perkembangan dan fenomena yang terjadi pada angka Jumlah Penduduk dan Pertumbuhan Ekonomi selama kurun waktu 18 tahun di Kota Lhokseumawe sebagai berikut:

\section{Tabel}

\section{Jumlah Penduduk dan Pertumbuhan Ekonomi} di Kota Lhokseumawe Tahun 2001-2018

\begin{tabular}{||c|c|c||}
\hline \hline Tahun & $\begin{array}{c}\text { Jumlah_Penduduk } \\
\text { (Jiwa) }\end{array}$ & $\begin{array}{c}\text { Pertumbuhan_Ekonomi } \\
\text { (\%) }\end{array}$ \\
\hline \hline 2014 & 187.455 & 4,36 \\
\hline 2015 & 191.407 & 2,9 \\
\hline 2016 & 195.186 & 2,24 \\
\hline 2017 & 198.980 & 1,89 \\
\hline 2018 & 203.284 & 1,11 \\
\hline \hline
\end{tabular}

Sumber: Badan Pusat Statistik (2019)

Data selama 18 tahun, pada tahun 2001 angka pertumbuhan ekonomi merupakan angka yang sangat kecil dibandingkan tahun-tahun berikutnya, angka pada tahun 2001 diperoleh sebesar -0,44\% karena pada tahun 2001 Lhokseumawe baru resmi berdiri sendiri yang sebelumnya merupakan salah satu kota pemekaran dari Kabupaten Aceh Utara, peresmian kota 
Lhokseumawe terjadi pada pertengahan tahun 2001 yaitu pada tanggal 21 Juni, sehingga hitungan pertumbuhan ekonomi di kota Lhokseumawe pada tahun tersebut hanya berkisar 1 semester saja, oleh sebab itulah angka pertumbuhan ekonomi begitu sangat kecil dari pada tahun sebelumnya, untuk permasalahannya sendiri dapat kita lihat dari tahun 2001-2018 di kota Lhokseumawe ada berbagai variasi dan terjadi secara fluktuatif. Masalah yang timbul pada variabel jumlah penduduk dari tahun 2001 - 2018 bahwa jumlah penduduk pada tahun 2001 sebesar 163.231 jiwa dan pada tahun 2002 jumlah penduduk sebesar 165.281 meningkat dari tahun sebelumnya namun pertumbuhan ekonomi di tahun tersebut meningkat dari tahun sebelumnya yaitu $-0,44 \%$ meningkat menjadi 7,96\%, kemudian pada tahun 2003 jumlah penduduk di Kota Lhokseumawe yaitu sebesar 167.362 jiwa dan ditahun 2004 jumlah penduduk menurun menjadi 138.663 jiwa namun pertumbuhan ekonomi juga menurun yaitu terjadi penurunan menjadi $1,76 \%$, selanjutnya permasalahan yang sama terjadi di tahun 2006 dan 2007, dimana jumlapenduduk di tahun 2006 sebesar 154.634 jiwa dan meningkat ditahun 2007 menjadi 156.556 jiwa, sedangkan untuk pertumbuhan ekonomi juga meningkat dari tahun sebelumnya menjadi $12,11 \%$. Kemudian terjadi masalah yang sama juga ditahun 2009 dan 2010 yaitu ditahun 2010 angka jumlah penduduk meningkat dari tahun sebelumnya menjadi 171.163 jiwa sedangkan untuk pertumbuhan ekonomi juga meningkat dari tahun sebelumnya menjadi 5,88 .

Oleh karena itulah terjadi masalah terhadap jumlah penduduk dengan pertumbuhan ekonomi yang masalah tersebut timbul dikarenakan tidak sesuai dengan teori, dimana teori disebutkan bahwa jumlah penduduk yng besarakan menurunkan pertumbuhan ekonomi (Rahayu, 2017).

Perkembangan penduduk menyebabkan besarnya las asar dai barang-barang yang dihasilkan dari perusahaan menjadibesar ula. Maka perkembangan pendudukan akan menimbulkan dorongan kepada pertambahan dalam produksi nasional dan tingkat kegiatan ekonomi (Sukirno, 2006).

Penelitian ini sejalan dengan penelitian yang dilakukan oleh (Rochaida, 2016) dengan judul dampak pertumbuhan penduduk terhadap pertumbuhan ekonomi dan keluarga sejahtera di Provinsi Kalimantan Timur, penelitian ini menggunakan metode deskriptif dengan diperoleh pembangunan melibatkan berbagai dimensi yang perlu dibangun, dan bukan hanya bersandar pada ekonomi semata. Perencanaan pembangunan meliputi berbagai aspek yang menyeluruh, ekonomi, sosial budaya, kependudukan termasuk pembangunan keluarga, sertapembangunanwilayah. Bahkan sekarang perencanaan pembangunan sekarang beriorientasi pada penduduk (pembangunan berwawasan kependudukan).

\section{KAJIAN TEORITIS}

\section{Pertumbuhan Ekonomi}

Pertumbuhan ekonomi adalah kenaikan kapasitas dalam jangka panjang dari negara yang bersangkutan untuk menyediakan berbagai barang ekonomi bagi penduduknya (Aliasuddin, 2016).

Pertumbuhanekonomi ialah suatu naiknya kapasitas nilai produksi sehingga pendapatan Nasional menmabh (Imam, 2016).

Dari penjelasan diatas dapat ditarik kesimpulan, bahwa pertumbuhan ekonomi merupakan proses meningkatnya jumlah barang dan jasa yang dihasikan oleh suatu negara dari tahun sebelumnya untuk kesejahteraan masyarakat didalamnya.

\section{Jumlah Penduduk}

Jumlah penduduk secara umum adalah total semua orang yang berdomisili di wilayah geografis suatu negara selama jangka waktu tertentu serta sudah memenuhi syarat-syarat yang telah ditentukan oleh peraturan Negara (https://ekspektasia.com.2019).

Jumlah penduduk adalah jumlah yang menempati suatu wilayah pada waktu tertentu (Mulyadi, 2008).

Jumlah penduduk adalah sekumpulan orang yang menetap dan juga berdomisili di dalam suatu negara (Nurdiman, 2008).

Berdasarkan para pakar diatas dapat disimpulkan bahwa jumlah penduduk adalah jumlah masyarakat yang tiggal apada suatu wilayah dan menetap untuk mendiami suatu daerah pada suatu waktu tertentu.

\section{Kerangka Konseptual}

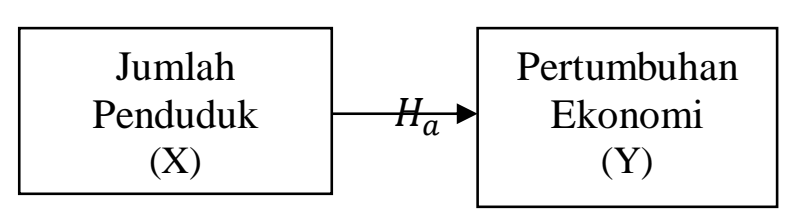

Gambar Kerangka Konseptual 


\section{Hipotesis}

Berdasarkan kerangka konseptual maka dapat diambil kesimpulan sebagi berikut:

$H_{0}$ : Jumlah penduduk tidak berpengaruh terhadap pertumbuhan ekonomi di Kota Lhokseumawe tahun 2001-2018

$H_{a}$ : Jumlah penduduk berpengaruh terhadap pertumbuhan ekonomi di Kota Lhokseumawe tahun 2001-2018

\section{METODE PENELITIAN}

\section{Objek dan Lokasi Penelitian}

Objek dalam penelitian ini yaitu jumlah penduduk dan pertumbuhan ekonomi. Lokasi penelitian ini dilakukan di Kota Lhokseumawe.

\section{Jenis dan Sumber Data}

Jenis data yang digunakan adalah data-data sekunder yang diperoleh melalui publikasi data yang dikeluarkan oleh Badan Pusat Statistik (BPS) Kota Lhokseumawe tahun 2001 sampai dengan 2018.

\section{Definisi Operasional Variabel}

1. Jumlah penduduk $(X)$ : jumlah masyarakat yang tinggal dan menetap untuk mendiami suatu daerah pada suatu waktu tertentu. Skala ukuran yang digunakan dalam Jiwa.

2. Pertumbuhan ekonomi (Y): proses meningkatnya jumlah barang dan jasa yang dihasikan oleh suatu negara dari tahun sebelumnya untuk kesejahteraan masyarakat didalamnya Skala ukuran yang digunakan dalam persen.

\section{Metode Analisis data}

Untuk memecahkan masalah penulis melakukan analisis data dengan memakai metode kuantitatif yaitu suatu metode menganalisis data yang diperoleh dalam bentuk angka dan selanjutnya akan dibahas serta di analisis dengan menggunakan alat statistik yaitu program Eviews versi 10 yang berupa metode Regresi Linier Sederhana (RLS).

Adapun formulanya adalah sebagai berikut :

$$
\mathbf{Y}=\boldsymbol{\beta}_{0}+\boldsymbol{\beta} X+e i
$$

$$
\begin{array}{cl}
\text { Dimana : } \mathrm{Y} & =\text { Pertumbuhan ekonomi } \\
\beta_{0} & =\text { Konstanta } \\
\beta & =\text { Koefisien regresi }
\end{array}
$$

$\begin{aligned} X & =\text { Jumlah Penduduk } \\ \mathrm{Ei} & =\text { Error Term }\end{aligned}$

\section{Uji Normalitas}

Uji normalitas dilihat untuk data terdistribusi secara normal atau tidak. Pengujian normalitas dapat dilakukan dengan menggunakan metode Jarque-Bera (J-B) (Widarjono, 2013).

Jika nilai probability dari statistik J-B lebih besar dari taraf kepercayaan 5\% $(0,05)$ berarti bahwa residul data berdistribusi normal. Sebaliknya jika nilai probability dari statistik J-B lebih kecil dari taraf kepercayaan 5\% $(0,05)$ berarti bahwa residul data tidak berdistribusi normal(Widarjono, 2013).

\section{Uji Autokorelasi}

Tes autokorelasi ini dimaksudkan untuk mengidentifikasi apakah ada korelasi antar keadaan variabel gangguan (disturbance) pada periode tertentu dengan variabel gangguan (disturbance) pada periode lain. Gejala autokorelasi ini dominan terjadi pada dta timeseries (Gujarati, 2004). Pendeteksian terhadap penyimpangan asumsi klasik untuk atuokorelasi dapat dilihat pada besarnya nilai Breusch-Godfrey Test. Jika nilai Obs. $R$-Squared tidak signifikan maka data tidak terjadi autokorelasi.

\section{Pengujian Hipotesis}

\section{Uji t}

Uji t dilakukan untuk melihat apakah ada hubungan variabel bebas dan variabel terikat secara parsial (Subri, 2013).

1. Jika $t_{\text {hitung }}>t_{\text {tabel }}$ Ho ditolakdan menerimaHa yang artinya variabel bebas (X) secara parsial mempengaruhi variabel terikat $(\mathrm{Y})$.

2. Jika $t_{\text {hiutng }}<t_{\text {tabel }}$ maka Ho diterima dan menolak Ha yang artinya variabel bebas (X) secara parsial tidak mempengaruhi vaiabel terikat (Y).

\section{Koefisien Korelasi (R)}

Menurut (Sugiyono, 2015) Koefisien korelasi untuk melihat sebesar besar angka hasilnya mempengaruhi variable lainnya sehingga dapat kita tetntukan hasilnya dalam standard mana.Hasilnya dapt ditentukan interpretasi koefisien sebagai berikut (Sugiyono, 2015):

- $>0,00-0,199=$ sangat rendah 
- $>0,20-0,399=$ rendah

- $>0,40-0,599=$ sedang

- $>0,60-0,799=$ kuat

- $>0,80-0,99=$ sangat kuat

- $>1=$ korelasi sempurna

\section{Koefisien Determinasi $\left(R^{2}\right)$}

Dilakukan unutk menguji adananya hubungan variable dependet dan indenpent dengan $0<R^{2}<1$. Secara sederhana koefisien determinasi dihitung dengan mengkuadratkan Koefisien Korelasi (R). (Subri, 2013).

\section{HASIL PENELITIAN DAN PEMBAHASAN}

\section{Hasil Regresi Linier Berganda \\ Tabel}

\section{HasilAnalisis RLS}

Dependent Variable: PERTUMBUHAN_EKONOMI

\begin{tabular}{cclrr} 
Variable & Coefficient & Std. Error & t-Statistic & \multicolumn{1}{l}{ Prob. } \\
\hline \hline $\begin{array}{c}\text { C } \\
\text { JUMLAH }\end{array}$ & 12.67346 & 6.707101 & 1.889558 & 0.0771 \\
PENDUDUK & -0.049820 & 0.038719 & -1.286709 & 0.2165 \\
\hline \hline $\begin{array}{l}\text { R-squared } \\
\text { Adjusted R- } \\
\text { squared }\end{array}$ & 0.093773 & F-statistic & 1.655620 \\
& 0.037134 & Prob(F-statistic) & 0.216502 \\
& & Durbin-Watson stat & 1.577020
\end{tabular}

Sumber: Hasil Penelitian, 2019 (data diolah)

Nilai konstanta sebesar 12.67346 artinya jika variabel jumlah penduduk bernilai nol, maka variabel dependen pertumbuhan ekonomi sebesar $12.67 \%$.

Nilai koefisien regresi jumlah penduduk sebesar -0,049820 menunjukkan hubungan negatif yang memberi arti jika variabel jumlah penduduk meningkat sebesar 1 jiwa makaaka menuunkan variabel pertumbuhan ekonomi sebesar $0,05 \%$, hal ini terjadi karena ketika jumlah penduduk meningkat namun penduduknya tidak produktif maka akan mengurangi kas pendapatan daerah, karena masyarakat didalamnya hanya mampu melakukan konsumsi tanpa dapat mengasilkan pendapatan suatu daerah. Sehingga apabila semakin besar masyarakat yang ada namun tidak produkstif makaakan enurunkan pertumbuhan ekonomi.
Uji Normalitas

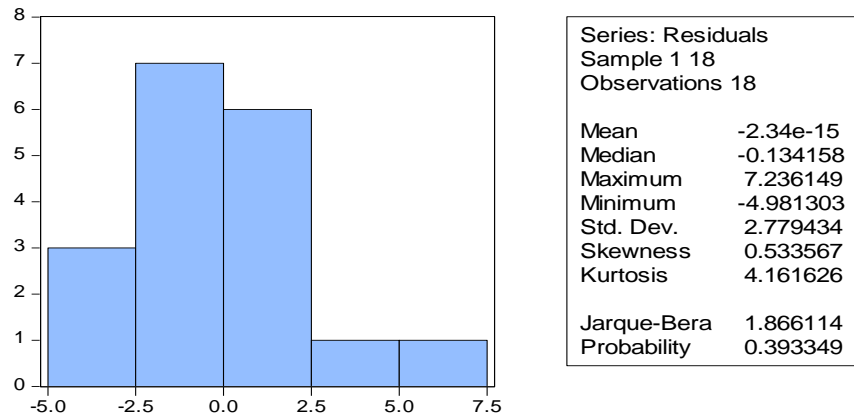

Sumber: Hasil Penelitian, 2019 (data diolah)

Gambar Uji Normalitas

Nilai $X^{2}$ (Chi-Square) tabel dengan df (2) $=5,99$. Jika dibandingkan dengan nilai J-B pada tabel 4.3 sebesar $1,87<5,99$, hasilnya diperloeh model regresi, variabel penggangu atau residual dalam model sudah terdistribusi dengan normal. Hal ini juga bisa dilihat dari probabilitas (P-value) sebesar 0,39>0,05.

\section{Hasil Uji Asumsi Klasik}

\section{Hasil Uji Autokorelasi}

\section{Tabel}

\section{Uji Autokorelasi}

Breusch-Godfrey Serial Correlation LM Test:

\begin{tabular}{llll}
\hline \hline F-statistic & 0.392616 & Prob. F(2,14) & 0.6825 \\
Obs ${ }^{*}$ R-squared & 0.955965 & Prob. Chi-Square(2) & 0.6200 \\
\hline \hline
\end{tabular}

Sumber: Hasil Penelitian, 2019 (data diolah)

Hasil tersebut dilihat dari $o b s * R$-Squared < $X^{2}$ (Chi-Square) tabel pada df (2) $=5,99$, sehingga $0,95<5,99$. Hal ini juga bisa dilihat dari nilai probability ( $\mathrm{P}$-value) sebesar 0,62>0,05.

\section{Pengujian Hipotesis}

\section{Uji t}

\section{Tabel Uji t}

\begin{tabular}{|l|l|l|l|l|}
\hline \multicolumn{5}{|c|}{ Variabel Dependen (Pertumbuhan Ekonomi) } \\
\hline $\begin{array}{l}\text { Varibael } \\
\text { Independen }\end{array}$ & $\begin{array}{l}\text { T- } \\
\text { Statistik }\end{array}$ & Prob & Keterangan & Hipotesis \\
\hline Jumlah Penduduk & -1.2867 & 0,216 & Tidak Sig & Menolak \\
\hline
\end{tabular}

Sumber: Hasil Penelitian,2019 (data diolah)

Nilai $t_{\text {hitung }}$ dari jumlah penduduk adalah sebesar -1,29 dengan nilai signifikannya adalah 0,2165 , sementara nilai $t_{\text {tabel }}$ dengan $(\mathrm{df})=\mathrm{n}-\mathrm{k}$ $(18-2=16)$ pada $\alpha=10 \%$ diperoleh nilai sebesar 
1,74 artinya $>$ derajat kesalahan sebesar $10 \%(0,1)$. Maka keputusannya menerima $H_{0}$ dan menolak $H_{a}$, yang berarti secara parsial jumlah penduduk tidak berpengaruh terhadap pertumbuhan ekonomi di Kota Lhokseumawe.

Pengaruh pertumbuhan ekonomi di kota Lhokseumawe tidak dikarenakan adanya jumlah pendudukan, namun pengaruh pertumbuhan ekonomi di Kota Lhokseumawe disebabkan karena PAD dan infrastruktur yang ada, karena jumlah penduduk yang besar di Lhokseumawe namun tidak memberikan sumbangan kontribusi yang produktif untuk kotanya, bahkan masyarakat didalamnya banyak melakukan belanja impor keluar daerah.

\section{Koefisien Korelasi (R)}

Nilai koefisien determinasi $\left(R^{2}\right)$ sebesar 0,0938 yang artinya bahwa variabel jumlah penduduk berpengaruh terhadap pertumbuhan ekonomi di provinsi Aceh sebesar 0,0938 (9,38\%), sedangkan $90,62 \%$ dipengaruhi oleh variabel lainnya diluar model penelitian ini.

\section{Koefisien Determinasi $\left(R^{2}\right)$}

\section{Adjusted R-Squared $=0,3061$}

Nilai koefisien korelasi adalah $R=\sqrt{R^{2}}=$ $\sqrt{0,0937}=0,3061(30,61 \%)$ yang menunjukkan bahwa hubungan antara variabel jumlah penduduk terhadap pertumbuhan ekonomi memiliki hubungan yang rendah secara positif karena nilai korelasi $30,61 \%$ belum mendekati positif satu $(+1)$.

\section{Pembahasan \\ Pengaruh Jumlah Penduduk Terhadap Pertumbuhan Ekonomi}

Berdasarkan hasil analisis data ditemukan bahwa variabel jumlah penduduk $(x)$ tidak berpengaruh dan negatif terhadap pertumbuhan ekonomi $(y)$ dengan nilai signifikan $\alpha=10 \%$. Hal ini bermakna bahwa semakin tinggi jumlah penduduk $(x)$, maka tidak akan menurunkan pertumbuhan ekonomi di Kota Lhokseumawe. Hal tersebut dikarenakan di Kota Lhokseumawe untuk pertumbuhan ekonomi tidak terlalu memfokuskan pada jumlah penduduk, namun yang difokuskan untuk meningkat pertumbuhan ekonomi adalah infrastuktur, peningkatan persektor yang akan mempengaruhi PDRB Kota Lhokseumawe, jumlah penduduk di Kota Lhokseumawe saat ini sudah sadar betapa pentingnya masyarakat produktif dibandingkan masyarakat yang konsumtif, selain menguntungkan bagi masyarakat itu sendiri juga menguntungkan bagi kegiatan perekonimian wilayahnya.

Hasil penelitian ini sejalan dengan penelitian yang dilakukan oleh (Aliasuddin, 2016) di Provinsi Aceh bahwa hasil yang diperoleh jumlah penduduk tidak berpengaruh dan signifikan, hal ini dikarenakan sumber daya manusia di Provinsi Aceh sudah mampu produktif untuk dirinya sendiri sehingga tanggung masyarakat miskin ada namun tidak begitu jelas terlihat.

\section{PENUTUP}

\section{Kesimpulan}

Hasil yang ditemukan variabel jumlah penduduk tidak berpengaruh secara negatif dan tidak signifikan terhadap pertumbuhan ekonomi di Kota Lhokseumawe, karena pengaruh pertumbuhan ekonomi di kota Lhokseumawe tidak dikarenakan adanya jumlah pendudukan, namun pengaruh pertumbuhan ekonomi di Kota Lhokseumawe disebabkan karena PAD dan infrastruktur yang ada, karena jumlah penduduk yang besar di Lhokseumawe namun tidak memberikan sumbangan kontribusi yang produktif untuk kotanya, bahkan masyarakat didalamnya banyak melakukan belanja impor keluar daerah.dan besarnya penerimaan jumlah penduduk terhadap pertumbuhan ekonomi adalah sebesar 0,0938 (9,38\%) sedangkan 90,62\% dipengaruhi oleh variabel lainnya diluar model penelitian ini.

\section{Saran}

Adapun beberapa saran-saran yang diharapkan penulis dalam penelitian ini adalah sebagai berikut:

- Hasil penelitian menunjukkan variabel yang diteliti tidak berpengaruh terhadap pertumbuhan ekonomi, tingginya jumlah penduduk tidak mempengaruhi pertumbuhan ekonomi di kota Lhokseumawe sehingga tidak sesuai teori. Dengan adanya perbedaan teori ini dapat menambah wawasan kepada peneliti untuk memperluas wawasan bahwasanya pertumbuhan ekonomi tidak hanya dipengaruhi oleh faktor di dalam penelitian ini saja, tetapi pertumbuhan ekonomi juga dipengaruhi oleh faktor-faktor didalam penentu pertumbuhan 
ekonomi seperti PDRB, pengangguran, inflasi, kemiskinan dll.

- Diharapkan kepada pemerintah daerah dan pemerintah pusat agar dapat membantu dan mendorong kegiatan pertumbuhan ekonomi di kota Lhokseumawe, dengan memperhatikan variabel-variabel penting seperti peneliti lakukan yaitu variabel jumlah penduduk dan pertumbuhan ekonomi yang menjadi salah satu menjadi tolak ukur bagi pembangunan ekonomi di kota Lhokseumawe.

- Perlu adanya penelitian lanjutan, sehingga diperoleh temuan yang lebih bervariasi dan lebih baik dalam menjelaskan variabel pertumbuhan ekonomi dengan metode penelitian yang berbeda.

\section{DAFTAR PUSTAKA}

1. Aliasuddin, S. I. dan. (2016). Pengaruh Penduduk Terhadap Pertumbuhan Ekonomi. Jurnal IImiah Mahasiswa (JIM), Vol 1(No.1).

2. Gujarati, D. (2004). Ekonometrika Dasar Terjemahan: Sumarno Zain. Jakarta: PT. Erlangga.

3. Imam, H. (2016). Ekonomi Makro Jakarta. Jakarta: PT. Fajar Interpratama.

4. Mulyadi, S. (2008). Ekonomi Sumber Daya Manusia Dalam Perspektif Pembangunan. Jakarta: Rajawali Press.

5. Nurdiman. (2008). Ekonomi Kependudukan. Jakarta: Raja Grafindo Persada.

6. Rahayu. (2017). Pengaruh Jumlah Penduduk Dan Inflasi Terhadap Terhadap Pertumbuhan Ekonomi. Jurnal JOM FEKON, Vol 2(No 2).

7. Rochaida, E. (2016). Dampak Pertumbuhan Penduduk Terhadap Pertumbuhan Ekonomi dan Kelaurga Sejahtera di Provinsi Kalimantan Timur. Jurnal Forum Ekonomi, Vol 18(No.1).

8. Rukmana, I. (2012). Pengaruh Disparitas Pendapatan, Jumlah Penduduk Dan Inflasi Terhadap Pertumbuhan Ekonomi Di Jawa Tengah Tahun 1984-2009. Economics
Development Analysis J, Journal Vo(No. 1).

9. Subri. (2013). Ekonomi Sumber Daya Manusia. (P. R. G. Persada, Ed.). Jakarta.

10. Sugiyono. (2015). Statistik Untuk Penelitian. Bandung: Alfabeta.

11. Sukirno, S. (2006). Pengantar Teori Makro. Jakarta: PT. Graha Grafindo.

12. Widarjono, A. (2013). Ekonometrika. Yogyakarta: Edisi Keempat. 